\title{
Sistem Informasi Geografis Sebaran Lokasi Pos Hujan Kerjasama Berbasis Web pada Stasiun Klimatologi Klas 1 Banjarbaru
}

\author{
Ade Kurniawan $^{1)}$, Veri Julianto ${ }^{2)}$ \\ 1)2) Jurusan Teknik Informatika, Politeknik Negeri Tanah Laut \\ Jl. A. Yani Km 6 Pelaihari Tanah Laut Kalimantan Selatan \\ 1) kurniawanade508@gmail.com; ${ }^{2)}$ verijulianto@gmail.com
}

\begin{abstract}
Abstrak - Stasiun Klimatologi Klas 1 Banjarbaru sebagai koordinator BMKG Provinsi Kalimantan Selatan mempunyai tugas untuk mengkoordinir jaringan pos-pos hujan kerjasama yang terdapat di Provinsi Kalimantan Selatan. Setiap Pos Hujan Kerjasama mempunyai tugas untuk mengamati kondisi lingkungan yang ada di sekitar pos hujan kerjasama. Proses Pencatatan masih menggunakan Microsoft Excel dan pencarian titik koordinat masing-masing lokasi yang diperlukan saat proses kunjungan ke berbagai lokasi tersebut yang menyebabkan pihak pegawai kesulitan dalam hal kunjungan dimana masih harus mencari satu persatu data lokasi pos hujan kerjasama yang menyebabkan terbuangnya waktu. Sistem Informasi Geografis Sebaran Lokasi Pos Hujan Kerjasama dibangun berbasis web menggunakan PHP dengan bantuan Google Maps. Pembangunan desain pada pembuatan sistem informasi geografis ini dengan menggunakan DFD.
\end{abstract}

Kata Kunci: Sistem Informasi Geografis, Pos Hujan Kerjasama, Google Maps, DFD

\section{PENDAHULUAN}

Teknologi informasi dibidang komputer mengalami kemajuan yang sangat pesat dan berkembang setiap saat dan telah banyak mempengaruhi manusia menuju masyarakat yang membutuhkan informasi yang cepat dan tepat. Komputer merupakan alat bantu yang sangat diperlukan dalam kegiatan sehari-hari untuk menyelesaikan suatu pekerjaan baik dalam instansi pemerintah maupun swasta, serta lembaga-lembaga pendidikan. Sudah menjadi suatu keharusan untuk meningkatkan efisiensi, daya saing, keakuratan, kecepatan operasional perusahaan / organisasi, khususnya pada instansi yang bertanggung jawab dan memiliki peran dalam bidang kemasyarakatan. Informasi yang dibutuhkan masyarakat saat ini salah satunya adalah kebutuhan informasi geografis.

Sistem Informasi Geografis (SIG) merupakan salah satu cara dalam penyelesaian masalah keruangan (spasial) di Indonesia. Peran serta SIG sangat diperlukan untuk memberikan informasi terhadap masyarakat tentang sebaran lokasi pos hujan kerjasama. Keberadaan SIG sebagai suatu teknologi di bidang pemetaan mempunyai berbagai macam kelebihan yang dapat menunjang atau membantu proses pemetaan di suatu wilayah tertentu.

Stasiun Klimatologi Klas 1 Banjarbaru sebagai koordinator BMKG Provinsi Kalimantan Selatan mempunyai tugas untuk mengkoordinir jaringan pospos hujan kerjasama yang terdapat di Provinsi Kalimantan Selatan. Setiap Pos Hujan Kerjasama mempunyai tugas untuk mengamati kondisi lingkungan yang ada di sekitar pos hujan kerjasama tersebut.

Proses Pencatatan masih menggunakan Microsoft Excel dan pencarian titik koordinat masing-masing lokasi yang diperlukan saat proses kunjungan ke berbagai lokasi tersebut yang menyebabkan pihak pegawai kesulitan dalam hal kunjungan dimana masih harus mencari satu persatu data lokasi pos hujan kerjasama yang menyebabkan terbuangnya waktu.

Berdasarkan permasalahan tersebut penulis mengambil judul "Sistem Informasi Geografis Sebaran Lokasi Pos Hujan Kerjasama Berbasis Web pada Stasiun Klimatologi Klas 1 Banjarbaru". Pembuatan Sistem Informasi Geografis ini diharapkan dapat mempermudah masyarakat dan pegawai dalam memperoleh informasi mengenai Sebaran Lokasi Pos Hujan Kerjasama tersebut secara maksimal.

\section{TINJAUAN PUSTAKA}

\subsection{Sistem Informasi Geografis}

Geographic Information System (GIS) merupakan sistem yang dirancang untuk bekerja dengan data yang tereferensi secara spasial atau koordinat-koordinat geografi. GIS memiliki kemampuan untuk melakukan pengolahan data dan melakukan operasi-operasi tertentu dengan menampilkan dan menganalisa data (Dyah P.A \& Arsandy, 2015).

Geographic Information System (GIS) merupakan sistem komputer yang berbasis pada sistem informasi yang digunakan untuk memberikan bentuk digital dan analisis terhadap permukaan geografi bumi (Ramadhani dkk, 2003).

Berdasarkan uraian tersebut dapat disimpulkan bahwa sistem informasi geografis yaitu sistem yang mengelola data spasial (koordinat) menjadi sebuah informasi geografis yang digunakan untuk keperluan tertentu yang berhubungan dengan pemetaan yang terdapat di permukan bumi.

\subsection{Pos Hujan Kerjasama}

Ketelitian pengukuran hujan dipengaruhi oleh jumlah stasiun hujan (rainfall networks) dan pola penyebarannya di dalam DAS. Penempatan stasiun hujan yang tepat baik lokasi, jumlah stasiun hujan, 
pola penyebarannya akan dapat diperoleh data yang akurat mengenai kedalaman, penyebaran dan intensitas hujannya (Pariarta, 2012).

Berdasarkan uraian tersebut dapat disimpulkan bahwa penempatan pos hujan (stasiun hujan) yang baik dapat menentukan akurat atau tidak nya data tersebut.

\subsection{Google Maps}

Google Map Service adalah sebuah jasa peta global virtual gratis dan online yang disediakan oleh perusahaan Google (Mahdia \& Noviyanto, 2013).

Berdasarkan uraian tersebut dapat disimpulkan bahwa Google Maps adalah sebuah peta virtual yang dapat menggambarkan keadaan permukaan bumi baik berupa satelit maupun maps.

\subsection{Entity Relationship Diagram (ERD)}

Entity Relationship Diagram (ERD) adalah sekumpulan cara atau peralatan untuk mendeskripsikan data-data atau objek-objek yang dibuat berdasarkan dan berasal dari dunia nyata yang disebut entitas (entity) serta hubungan (relationship) antar entitas-entitas tersebut dengan menggunakan beberapa notasi (Edi \& Bethshani, 2009).

Tabel 1. Simbol Entity Relationship Diagram (ERD)

\begin{tabular}{|c|c|c|}
\hline Notasi & Komponen & Keterangan \\
\hline & Entitas & $\begin{array}{l}\text { Individu yang mewakili } \\
\text { suatu objek dan dapat } \\
\text { dibedakan dengan objek } \\
\text { yang lain. }\end{array}$ \\
\hline & Atribut & $\begin{array}{l}\text { Properti yang dimiliki oleh } \\
\text { entitas, dimana dapat } \\
\text { mendeskripsikan } \\
\text { karakteristik dari entitas } \\
\text { tersebut. }\end{array}$ \\
\hline & Relasi & $\begin{array}{l}\text { Menunjukkan hubungan } \\
\text { diantara sejumlah entitas } \\
\text { yang berbeda. }\end{array}$ \\
\hline & Relasi $1: 1$ & $\begin{array}{l}\text { Relasi yang menunjukkan } \\
\text { bahwa setiap entitas pada } \\
\text { himpunan entitas pertama } \\
\text { berhubungan dengan paling } \\
\text { banyak satu entitas pada } \\
\text { himpunan entitas kedua. }\end{array}$ \\
\hline & Relasi $1: \mathrm{N}$ & \begin{tabular}{|lrr} 
Relasi yang menunjukkan \\
bahwa hubungan antara \\
entitas pertama dengan \\
entitas kedua adalah satu \\
banding banyak atau \\
sebaliknya. Setiap entitas \\
dapat berelasi dengan \\
banyak entitas pada \\
himpunan entitas yang lain \\
\end{tabular} \\
\hline & Relasi N : N & $\begin{array}{l}\text { Hubungan ini menunjukkan } \\
\text { bahwa setiap entitas pada } \\
\text { himpunan entitas yang } \\
\text { pertama dapat berhubungan } \\
\text { dengan banyak entitas pada } \\
\text { himpunan entitas yang } \\
\text { kedua, demikian juga } \\
\text { sebaliknya }\end{array}$ \\
\hline
\end{tabular}

Sumber: Edi \& Betshani (2009)

\subsection{Data Flow Diagram (DFD)}

DFD adalah suatu model logika data atau proses yang dibuat untuk menggambarkan dari mana asal data dan kemana tujuan data yang keluar dari sistem dimana data disimpan proses apa yang menghasilkan data tersebut.

DFD terdiri dari context diagram dan diagram rinci (DFD Levelled). Context diagram berfungsi memetakan model lingkungan (menggambarkan hubungan antara entitas luar, masukan dan keluaran sistem), yang direpresentasikan dengan lingkaran tunggal yang mewakili keseluruhan sistem. DFD levelled menggambarkan sistem sebagai jaringan kerja antara fungsi yang berhubungan satu sama lain dengan aliran dan penyimpanan data, model ini hanya memodelkan sistem dari sudut pandang fungsi.

Dalam DFD levelled akan terjadi penurunan level dimana dalam penurunan level yang lebih rendah harus mampu merepresentasikan proses tersebut ke dalam spesifikasi proses yang jelas (Christianti \& Handoko, 2010).

Tabel 2. Simbol DFD

\begin{tabular}{|c|c|c|c|}
\hline Simbol & $\begin{array}{c}\text { Yourdon } \\
\text { dan } \\
\text { DeMarco } \\
\end{array}$ & $\begin{array}{c}\text { Gane } \\
\text { dan } \\
\text { Sarson }\end{array}$ & Keterangan \\
\hline $\begin{array}{c}\text { Entitas } \\
\text { Eksternal }\end{array}$ & & & $\begin{array}{l}\text { Entitas eksternal, } \\
\text { dapat berupa } \\
\text { orang/unit terkait } \\
\text { yang berinteraksi } \\
\text { dengan sistem } \\
\text { tetapi diluar sistem }\end{array}$ \\
\hline Proses & & & $\begin{array}{l}\text { Orang, unit yang } \\
\text { mempergunakan } \\
\text { atau melakukan } \\
\text { transformasi data. } \\
\text { Komponen fisik tidak } \\
\text { diidentifikasikan. }\end{array}$ \\
\hline $\begin{array}{c}\text { Aliran } \\
\text { data }\end{array}$ & & & $\begin{array}{l}\text { Aliran data dengan } \\
\text { arah khusus dari } \\
\text { sumber ke tujuan }\end{array}$ \\
\hline $\begin{array}{l}\text { Data } \\
\text { Store }\end{array}$ & & & $\begin{array}{l}\text { Penyimpanan data } \\
\text { atau tempat data } \\
\text { dituju oleh proses. }\end{array}$ \\
\hline
\end{tabular}

Sumber: Christianti \& Handoko (2010)

\subsection{Flowchart}

Flowchart adalah penggambaran secara grafik dari langkah-langkah dan urut-urutan prosedur dari suatu program. Flowchart menolong analis dan programmer untuk memecahkan masalah kedalam segmen-segmen yang lebih kecil dan menolong dalam menganalisis alternatif-alternatif lain dalam pengoperasian.

Flowchart biasanya mempermudah penyelesaian suatu masalah khususnya masalah yang perlu dipelajari dan dievaluasi lebih lanjut. Bila seorang analis dan programmer akan membuat flowchart, ada beberapa petunjuk yang harus diperhatikan, seperti (Sulindawati \& Fathoni, 2010):

1. Flowchart digambarkan dari halaman atas ke bawah dan dari kiri ke kanan. 
2. Aktivitas yang digambarkan harus didefinisikan secara hati-hati dan definisi ini harus dapat dimengerti oleh pembacanya.

3. Kapan aktivitas dimulai dan berakhir harus ditentukan secara jelas.

4. Setiap langkah dari aktivitas harus diuraikan dengan menggunakan deskripsi kata kerja, misalkan MENGHITUNG PAJAK PENJUALAN.

5. Setiap langkah dari aktivitas harus berada pada urutan yang benar.

6. Lingkup dan range dari aktifitas yang sedang digambarkan harus ditelusuri dengan hati-hati. Percabangan-percabangan yang memotong aktivitas yang sedang digambarkan tidak perlu digambarkan pada flowchart yang sama. Simbol konektor harus digunakan dan percabangannya diletakan pada halaman yang terpisah atau hilangkan seluruhnya bila percabangannya tidak berkaitan dengan sistem.

7. Gunakan simbol-simbol flowchart yang standar.

\section{METODE PENELITIAN}

Penelitian ini menggunakan tahapan-tahapan yang harus dilakukan agar aplikasi dapat terbangun. Penelitian ini menggunakan model SDLC (System Development Life Cycle) yaitu metode prototyping. Metode ini adalah pengembangan dari metode waterfall yang menerapkan sedikit inovasi.

Pembangunan sistem informasi geografis ini mengunakan metode prototyping dikarenakan perlu ada koordinasi dengan pihak pengguna yaitu dengan menunjukan setiap modul yang dibuat kepada pengguna yang dalam hal ini adalah bagian monitoring dari BMKG. Jika sudah sesuai dengan konsep pengguna maka dilanjutkan ketahap sesudahnya tetapi jika tidak maka akan dilakukan perbaikan sesuai dengan permintaan pengguna.

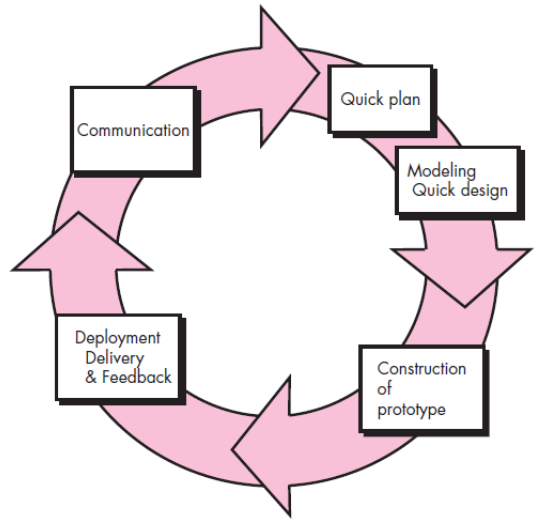

Gambar 1. Metode protyping

Penerapan metode prtotyping dalam penelitian ini yaitu:

a. Requirement Analysis

Pada tahap ini baik pengembang maupun pihak BMKG bersama-sama melakukan identifikasi kebutuhan, mendefinisikan format sistem yang akan dibangun, serta batasan-batasan sistem yang akan dibangun.

\section{b. Build Prototype}

Pada tahapan kedua ini dibuat prototype dari sebuah sistem yang akan dibangun, namun prototype ini hanya difokuskan pada penyajian kepada pihak BMKG meliputi inputan dan bentuk laporan yang sesuai dengan keinginan pihak BMKG.

c. Prototype Evaluation

Tahapan ini dilakukan oleh pihak BMKG apakah prototype yang dibuat sudah sesuai dengan kebutuhannya atau tidak, jika sesuai maka akan diimplementasikan, namun jika tidak prototype direvisi dan dibuat kembali untuk ditunjukkan kembali pada pihak BMKG.

\section{d. Implementation}

Setelah prototype sesuai dengan kebutuhan BMKG dan sudah disepakati bersama, maka tahapan implementasi dilakukan yakni dengan membuat program yang sesungguhnya dengan menggunakan bahasa pemrograman yang sesuai.

e. Testing

Setelah sistem yang dibangun menjadi satu kesatuan program yang utuh dan siap pakai, sebelum digunakan diperlukan pengujian. Sistem pengujian dilakukan pertama kali dengan pengujian white box, pengujian dilakukan oleh programmer atau sistem analis. Selanjutnya dilakukan pengujian dengan black box, pengujian dilakukan oleh user selain pembuat program. Pengujian ini dilakukan untuk mengetahui tingkat margin error dari program sebelum digunakan oleh pihak BMKG.

f. System Evaluation

Tahapan ini dilakukan oleh pihak BMKG dengan melakukan evaluasi apakah sistem yang didapatkan sudah sesuai dengan yang diharapkan. Jika sistem sudah sesuai, maka akan diimplementasikan.

g. Use the System

Tahap ini adalah tahap penggunaan sistem yang sudah diuji dan sudah dievaluasi terlebih dahulu.

\section{HASIL DAN PEMBAHASAN \\ 4.1 Perancangan Sistem \\ 4.1.1 ERD (Entity Relation Diagram)}

Gambar 2 mendeskripsikan entity relationship diagram yang mempunyai lima entitas yaitu Entitas tb_admin memiliki atribut id_admin, nama_lengkap, username, password dan email. Entitas tb_jenis memiliki atribut id_jenis, jenis_pos. Entitas tb_kabupaten memiliki atribut id_kab, nama_kab. Entitas tb_info memiliki atribut id_pos, nama_pos, lat, lng, icon, name, no_pos, elevasi, nama_pengamat, pengelola, alamat_pos, id_jenis dan id_kab. Entitas view_info atribut id_pos, nama_pos, lat, lng, icon, name, no_pos, elevasi, nama_pengamat, pengelola, alamat_pos, jenis_pos dan nama_kab. tb_jenis, tb_kabupaten, tb_info saling berelasi ke view_info. 


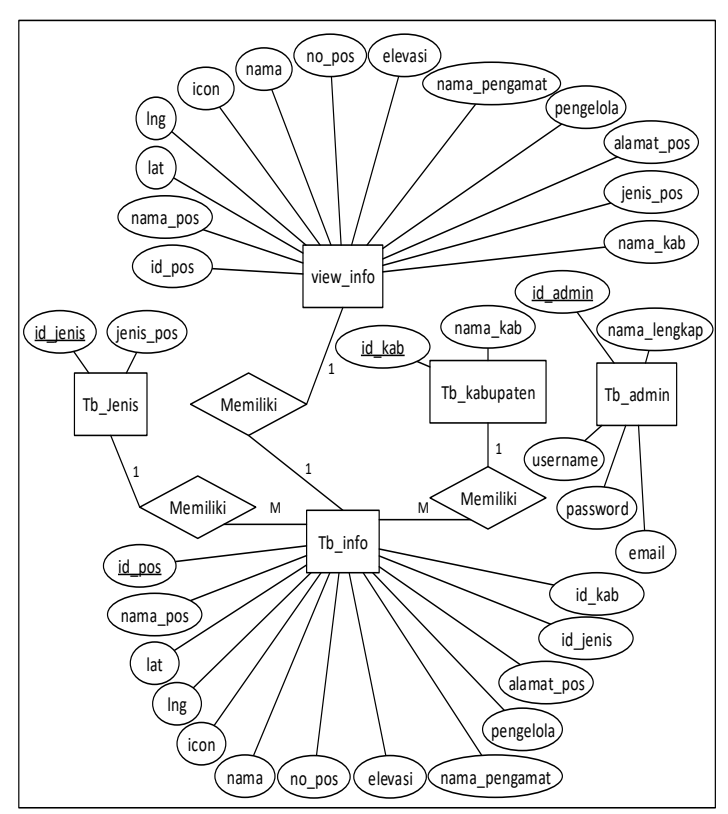

Gambar 2. ERD (Entity Relation Diagram)

\subsubsection{Data Flow Diagram (DFD)}

\subsubsection{Diagram Konteks}

Diagram Konteks Sistem Informasi Geografis Sebaran Lokasi Pos Hujan Kerjasama di Stasiun Klimatologi Klas 1 Banjarbaru dapat dilihat pada Gambar 3.

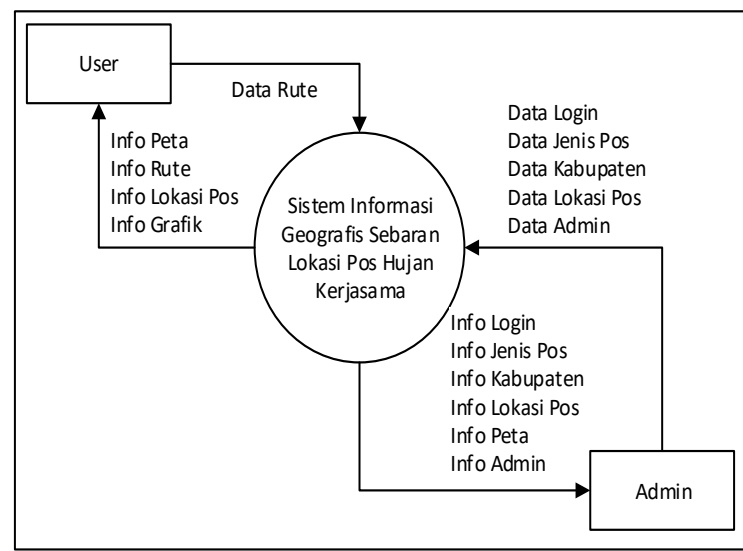

Gambar 3. Diagram Konteks

Gambar 3 mendeskripsikan diagram konteks yang menggambarkan aplikasi dikelola oleh admin, admin bertugas untuk menginputkan data seperti data jenis pos, data kabupaten, data lokasi pos, data admin. Sedangkan user dapat mencari data rute, melihat rute ke lokasi pos, melihat peta lokasi pos.

\subsubsection{Data Flow Diagram (DFD) Level 0}

Data Flow Diagram (DFD) Level 0 Sistem Informasi Geografis Sebaran Lokasi Pos Hujan Kerjasama di Stasiun Klimatologi Klas 1 Banjarbaru dapat dilihat pada Gambar 4.

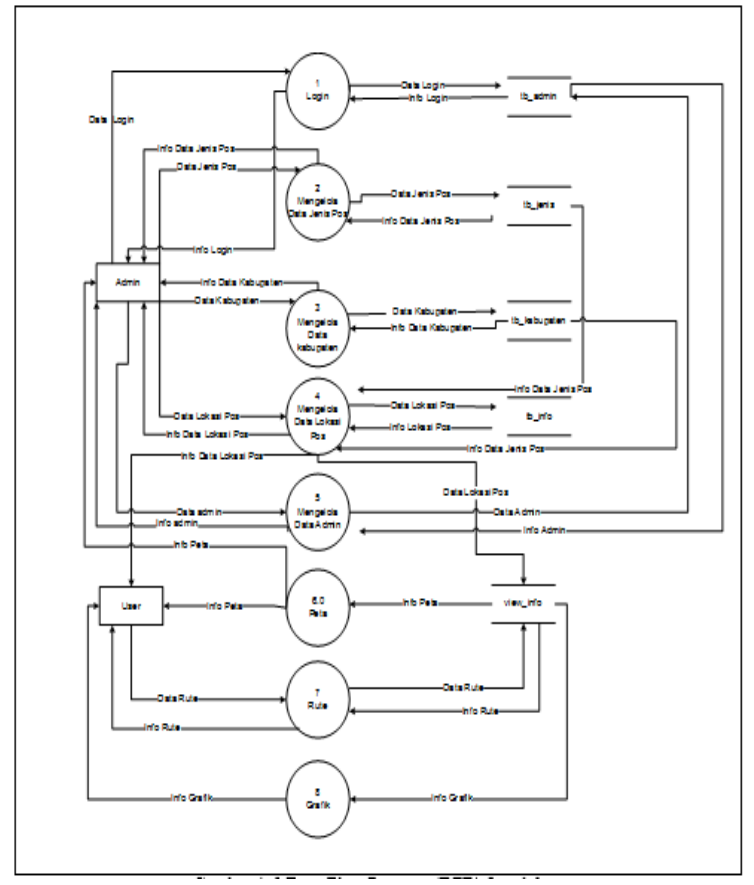

Gambar 4. Data Flow Diagram (DFD) Level 0

Gambar 4 mendeskripsikan data flow diagram (DFD) level 0, dimana admin dapat melakukan proses login, input data jenis pos, kabupaten, lokasi pos, dan dari menginputkan data lokasi pos data nya akan masuk juga ke peta, rute dan grafik. admin dapat melihat peta. Sedangkan user hanya dapat melihat peta, melakukan pencarian rute, melihat rute, melihat data lokasi pos, mencetak data lokasi pos dan melihat grafik jenis pos tanpa perlu login.

\subsection{Implementasi}

\subsubsection{Implementasi Halaman Beranda User}

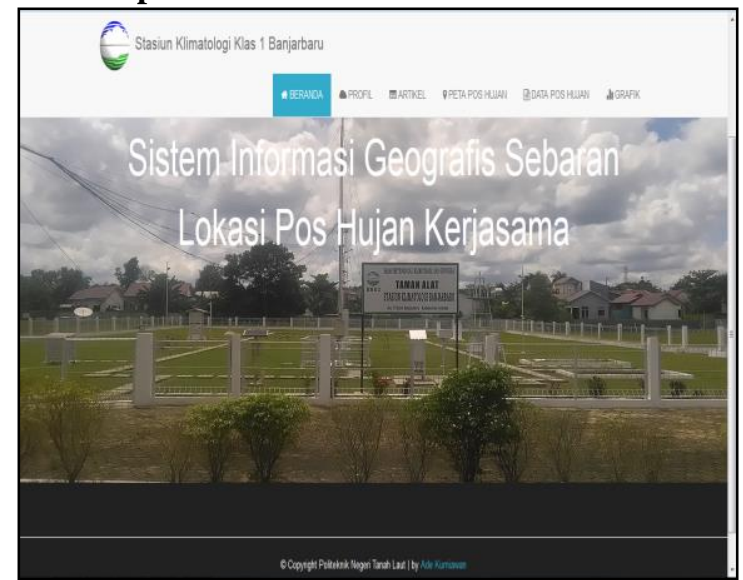

Gambar 5. Implementasi Halaman Beranda User

Gambar 5 adalah Implementasi dari Halaman Beranda User. Halaman Beranda User adalah tampilan awal ketika masuk ke Website. 


\subsubsection{Implementasi Halaman Peta Pos Hujan}

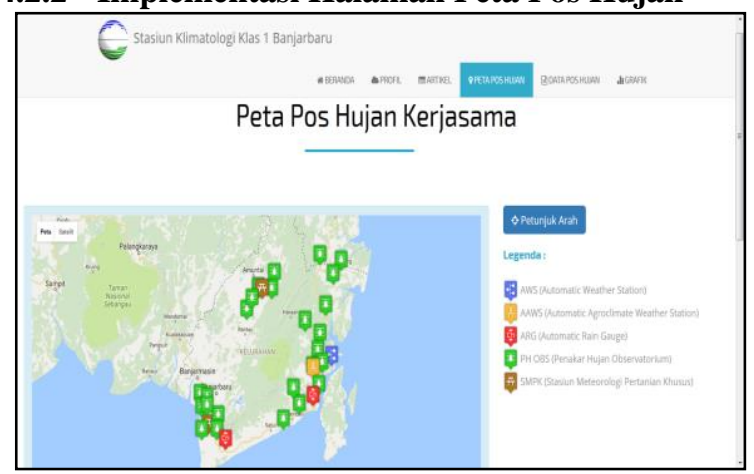

Gambar 6. Implementasi Halaman Peta Pos Hujan

Gambar 6 adalah Implementasi dari Halaman Peta Pos Hujan. Halaman Peta Pos Hujan adalah tampilan Peta yang ada pada halaman User. Pada Halaman Peta Pos Hujan, User dapat melihat titik-titik koordinat Lokasi Pos Hujan yang sudah dimasukkan ke dalam SIG.

\subsubsection{Implementasi Halaman Rute User}

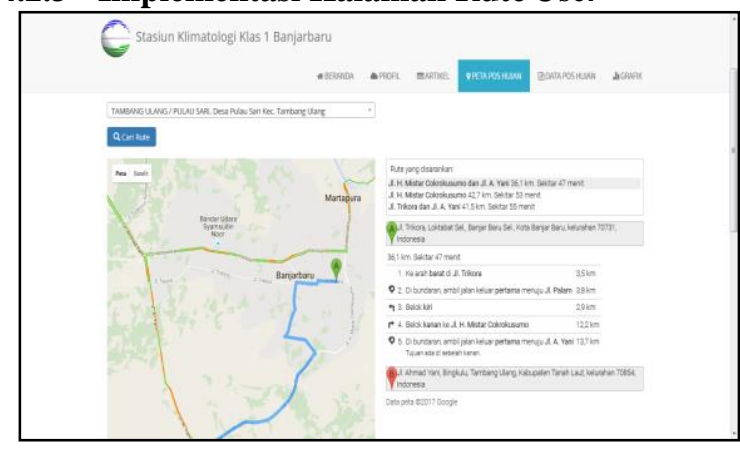

Gambar 7. Implementasi Halaman Rute User

Gambar 7 adalah Implementasi dari Halaman lihat rute User. Pada Halaman Rute User akan membaca posisi keberadaan User dengan warna simbol hijau menuju simbol merah dan akan memberikan informasi jalurnya.

\subsubsection{Implementasi Halaman Grafik User}

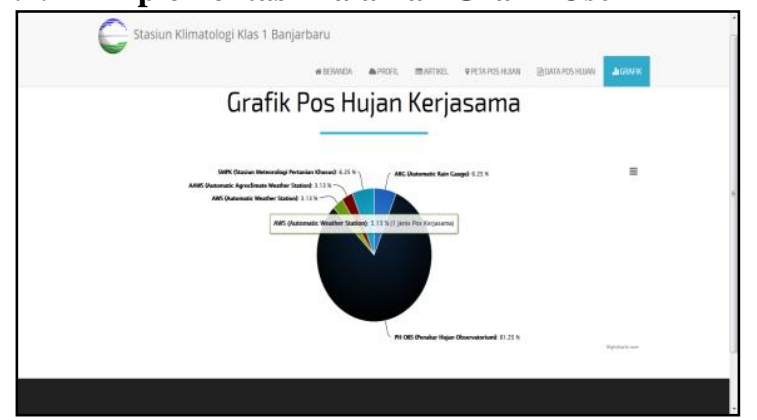

Gambar 8. Implementasi Halaman Grafik User

Gambar 8 adalah Implementasi dari Halaman Grafik User. Halaman Grafik User akan menampilkan berapa jumlah jenis pos hujan yang ada.

\subsubsection{Implementasi Halaman Login Admin}

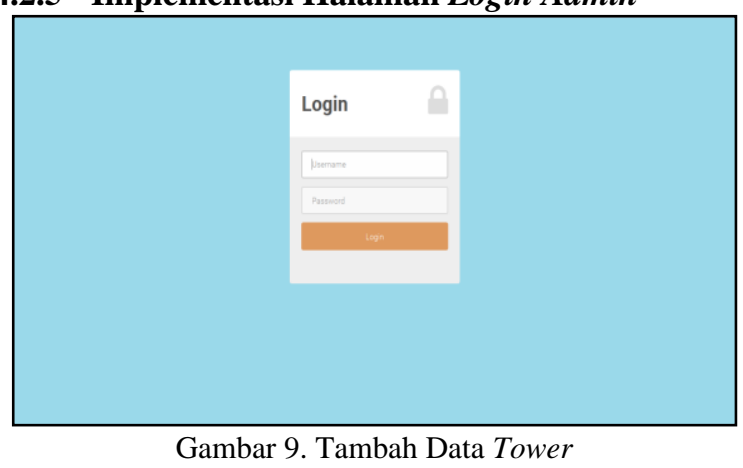

Gambar 9 adalah Implementasi dari Halaman Login Admin. Implementasi Halaman Login Admin menjelaskan tentang halaman utama dimana admin harus melakukan login terlebih dahulu pada halaman login dengan menginputkan username dan password yang benar.

\subsubsection{Implementasi Halaman Lokasi Pos}

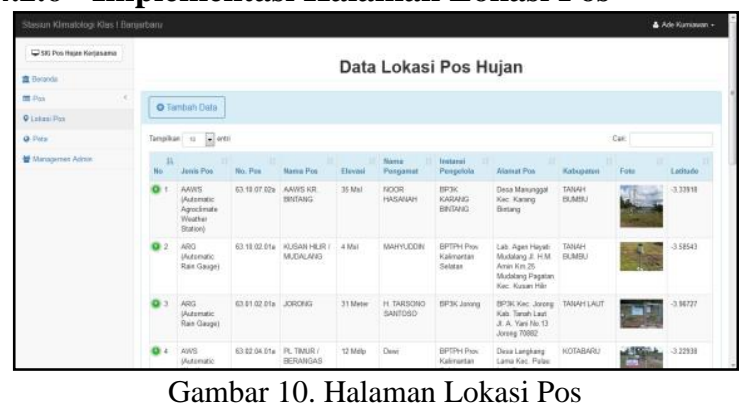

Gambar 10 adalah Implementasi dari Halaman Lokasi Pos Admin. Halaman Lokasi Pos Admin adalah Halaman yang didalamnya berisi tabel data lokasi pos dengan beberapa fungsi yaitu, menambah, mengubah, dan menghapus data lokasi pos.

\subsubsection{Implementasi Form Tambah Lokasi Pos}

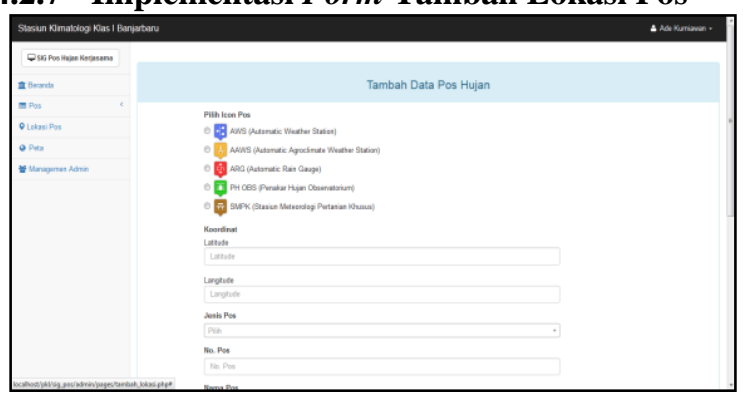

Gambar 11. Form Tambah Lokasi Pos

Gambar 11 adalah Implementasi dari Form Tambah Lokasi Pos. Admin diberikan hak akses untuk menambahkan data lokasi pos sesuai format yang telah ditentukan.

\subsection{Hasil Pengujian dan Pembahasan}

Pengujian sistem pada penelitian ini yaitu dengan menggunakan black box dan didapatkan hasil seperti berikut: 
Tabel 3. Hasil pengujian

\begin{tabular}{|c|l|c|}
\hline No. & Sekenario Penyajian & Hasil pengujian \\
\hline 1. & Fungsi login & Berhasil \\
\hline 2. & $\begin{array}{l}\text { Fungsi Tambah data pos } \\
\text { hujan }\end{array}$ & Berhasil \\
\hline 3. & Fungsi menampilkan grafik & Berhasil \\
\hline 4. & Fungsi Hapus data pos & Berhasil \\
\hline 5. & Fungsi edit data pos & Berhasil \\
\hline 6. & Fungsi lihat peta & Berhasil \\
\hline 7. & Fungsi lihat rute & Berhasil \\
\hline 8 & Fungsi tambah data admin & Berhasil \\
\hline 9. & Fungsi hapus data admin & Berhasil \\
\hline
\end{tabular}

Pengujian dilakukan dengan mengharapkan semua fungsi dapat berjalan. Hali ini dapat dijadikan sebagai tolak ukur bahwa permasalahan yang dihadapi terkait dengan pencataatan pos pengamatan hujan dapat teratasi. Selain itu juga dalam melakukan kunjungan ke posisi pos maka petugas dapat menggunakan aplikasi ini sebagai alat bantu mencari posisi pos yang diinginkan dan dapat menggunakan penunjuk arah melalui fungsi rute yang harus dilalui sehingga dapat menghemat waktu pencarian.

\section{KESIMPULAN}

Kesimpulan yang dapat diambil adalah telah dibuat Sistem Informasi Geografis Sebaran Lokasi Pos Hujan Kerjasama Berbasis Web pada Stasiun Klimatologi Klas 1 Banjarbaru yaitu Sistem informasi geografis ini dibangun dengan bahasa pemrograman PHP dan MySQL untuk aplikasi database nya yang diharapkan dapat mempermudah pencarian sebaran lokasi pos hujan kerjasama.

\section{DAFTAR PUSTAKA}

Christianti, M. \& Handoko, T. 2010. Aplikasi Pemesanan Kamar Serta Pengelolaan Data Kamar Secara Mobile pada Hotel Le Beringin. Jurnal Sistem Informasi. Vol. 5, No. 2, September 2010 : $123-140$.

Dyah P.A, N.R. \& Arsandy, E.R. 2015. Sistem Informasi Geografis Tempat Praktek Dokter Spesialis di Provinsi D.I. Yogyakarta Berbasis Web. Jurnal Informatika Mulawarman. Vol. 10 No. 1, Edisi Februari 2015.
Edi, D. \& Betshani, S. 2009. Analisis Data dengan Menggunakan ERD dan Model Konseptual Data Warehouse. Jurnal Informatika. Vol. 5, No. 1, Juni $2009: 71-85$.

Ramadhani, S., Anis, U. \& Masruro, S.T. 2013. Rancang Bangun Sistem Informasi Geografis Layanan Kesehatan Di Kecamatan Lamongan Dengan PHP MySQL. Jurnal Teknika. Vol. 5 No.2, September 2013. ISSN No. 2085 - 0859.

Mahdia, F. \& Noviyanto, F. 2013. Pemanfaatan Google Maps Api untuk Pembangunan Sistem Informasi Manajemen Bantuan Logistik Pasca Bencana Alam Berbasis Mobile Web. Jurnal Sarjana Teknik Informatika. Volume 1 Nomor 1, Juni 2013. ISSN: 2338-5197.

Pariarta, P.G.S. 2012. Analisis Pola Penempatan dan Jumlah Stasiun Hujan berdasarkan Persamaan Kagan pada DAS Keduang Waduk Wonogiri. Jurnal Ilmiah Teknik Sipil. Vol. 16, No. 1. Januari 2012.

Sulindawati \& Fathoni, M. 2010. Pengantar Analisa Perancangan "Sistem". Jurnal Saintikom. Vol. 9, No. 2 Agustus 2010.

\section{Biodata Penulis}

Ade Kurniawan, lahir di Pelaihari pada tanggal 23 Mei 1995. Penulis pertama menyelesaikan Sekolah Menengah Atas pada tahun 2014 dan melanjutkan pendidikan ke Politeknik Negeri Tanah Laut. Saat ini penulis pertama telah menempuh semester VI di Jurusan Teknik Informatika Politeknik Negeri Tanah Laut dan sedang menyelesaikan Tugas Akhir untuk memperoleh gelar A.Md.

Veri Julianto, M.Si, lahir di Gunung Makmur pada tanggal 11 Juli 1990. Penulis kedua memperoleh gelar S.Si dalam bidang Matematika di FMIPA UNLAM kemudian melanjutkan pendidikan Strata 2 di jurusan Komputasi Institut Teknologi Bandung dan memperoleh gelar M.Si pada tahun 2004. Selama penulis menempuh pendidikan Strata 2, penulis memfokuskan untuk mengkaji bidang Optimasi. Setelah memperoleh gelar Magister, penulis bekerja menjadi Dosen di jurusan Teknik Informatika Politeknik Negeri Tanah Laut mulai tahun 2014. 